\title{
Uncommon cause for chest pain
}

\author{
Preyander Thakur Singh, ${ }^{1}$ Deepak Burad, ${ }^{2}$ Julie Hephzibah, ${ }^{3}$ Thomas Vizhalil Paul ${ }^{1}$
}

${ }^{1}$ Christian Medical College Vellore, Tamil Nadu, India ${ }^{2}$ Department of Pathology, Christian Medical College, Vellore, Tamil Nadu, India ${ }^{3}$ Department of Nuclear Medicine, Christian Medical College, Vellore, Tamil Nadu, India

\section{Correspondence to} Professor Thomas Vizhalil Paul, thomasvpaul@yahoo.com

Accepted 14 February 2018

\section{DESCRIPTION}

A man aged 26 years presented with pain in the left side of the chest for 9 months, which was increasing on respiration and movement. However, patient did not have exertional dyspnoea, fever, skin lesions, history of trauma, weight loss or loss of appetite. On examination, patient had localised tender swelling on the lower part of left side of the chest with no other bony deformity or facial asymmetry. Chest X-ray posteroanterior view (figure 1) revealed radioluscent expansile lytic lesion in the left eighth rib. Clinical biochemistry revealed an elevated alkacalcium $9.5 \mathrm{mg} / \mathrm{dL}$ (normal: 8.3-10.4), phosphate $4 \mathrm{mg} / \mathrm{dL}$ (normal: $2.5-4.6$ ) and 25-hydroxyvitamin-D $28 \mathrm{ng} / \mathrm{mL}$ (normal: 30-75). Tc ${ }^{99} \mathrm{~m}$-labelled methylene diphosphonate bone scan (figure 2) revealed increased tracer uptake only in the left eighth rib. The biopsy of the affected rib was performed which on histopathological examination (figure 3) showed irregular trabeculae of woven bone lacking osteoblastic rimming, set in a fibrous stroma suggestive of fibrous dysplasia. Patient was treated with an oral bisphosphonate (alendronate $70 \mathrm{mg}$ once weekly) and was reviewed after 6 months, there was a significant reduction in the pain.

Fibrous dysplasia is a rare benign bone disorder caused by the postgenetic activating mutation of GNAS 1 gene. It is characterised by replacement of normal bone marrow with fibrous tissue due to abnormal osteoblastic activity leading to increase in osteoclast activity. It can be either monostotic (involving one bone) or

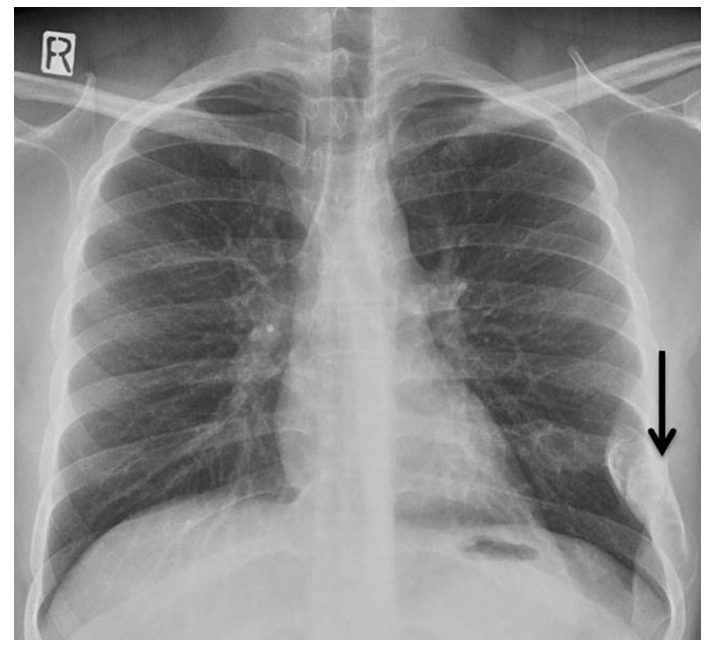

Hephzibah J, et al. BMJ Case Rep Published Online First: [please include Day Month Year]. doi:10.1136/bcr-2017223488

Figure 1 Chest $\mathrm{X}$-ray posteroanterior view showing radioluscent expansile lesion on left eighth rib suggestive line phosphatase at $224 \mathrm{U} / \mathrm{L}$ (normal: 40-125),
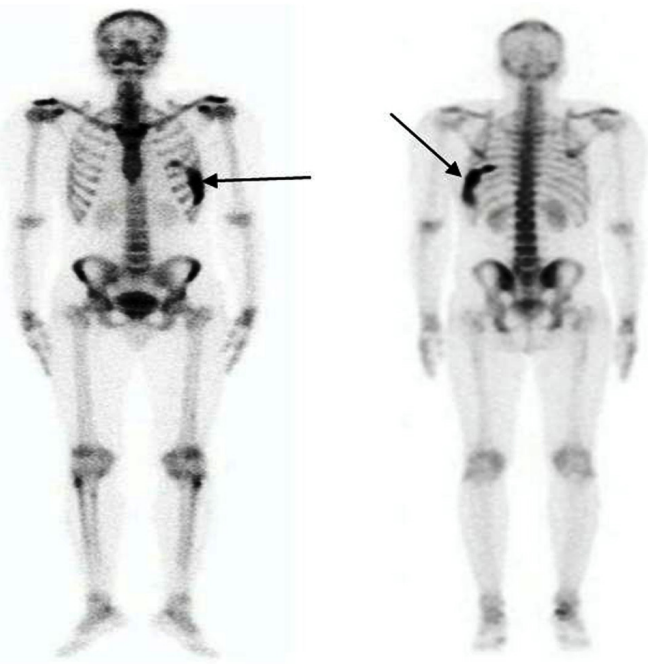

Figure 2 T ${ }^{99} \mathrm{~m}$-labelled methylene diphosphonate scan (anterior and posterior view) showing increased tracer uptake in left eighth rib.

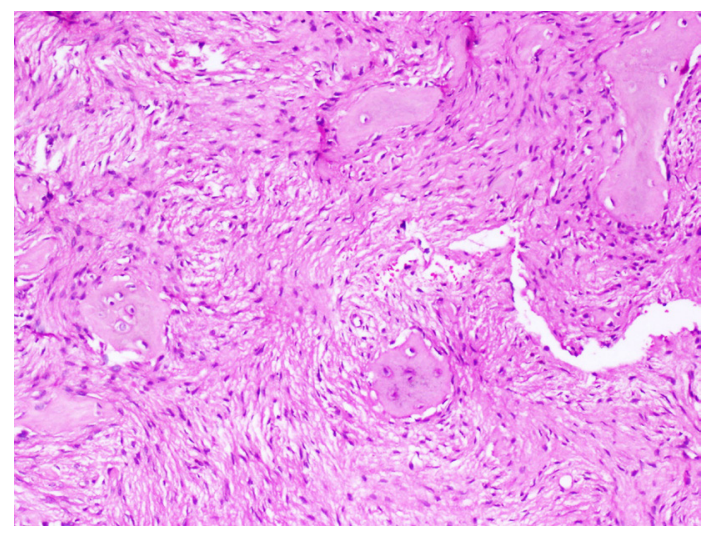

Figure 3 Irregular woven bone without osteoblastic rimming with surrounding proliferated bland spindle cells. H\&E 100x.

polyostotic (involving multiple bones). Craniofacial bones, ribs and proximal femur are the most frequent locations in monostotic forms.

\section{Learning points}

- Bone pain is the most common symptom of fibrous dysplasia.

- Patients with polyostotic form should be screened for endocrinopathies like hyperparathyroidism, acromegaly, Cushing's syndrome, hyperthyroidism as they can have McCune-Albright syndrome. of fibrous dysplasia. 
McCune-Albright syndrome should be suspected in patients with polyostotic form of fibrous dysplasia. Bone pain is the most common symptom with proximal femur, tibia and facial bones being the common bones involved, however can involve any bone in the body. ${ }^{1}$ Bisphosphonate therapy can be used to reduce pain in some patients. ${ }^{2}$

Contributors PTS: wrote the manuscript. DB, JH, TVP: reviewed the manuscript. PTS, DB, JH, TVP: finally approved the manuscript.

Funding This research received no specific grant from any funding agency in the public, commercial or not-for-profit sectors.

Competing interests None declared.
Patient consent Obtained.

Provenance and peer review Not commissioned; externally peer reviewed.

(C) BMJ Publishing Group Ltd (unless otherwise stated in the text of the article) 2018. All rights reserved. No commercial use is permitted unless otherwise expressly granted.

\section{REFERENCES}

1 Bhadada SK, Bhansali A, Das S, et al. Fibrous dysplasia \& McCune-Albright syndrome: an experience from a tertiary care centre in north India. Indian J Med Res 2011;133:504-9.

2 Majoor BC, Appelman-Dijkstra NM, Fiocco M, et al. Outcome of long-term bisphosphonate therapy in McCune-Albright syndrome and polyostotic fibrous dysplasia. J Bone Miner Res 2017;32:264-76.

Copyright 2018 BMJ Publishing Group. All rights reserved. For permission to reuse any of this content visit

http://group.bmj.com/group/rights-licensing/permissions.

BMJ Case Report Fellows may re-use this article for personal use and teaching without any further permission.

Become a Fellow of BMJ Case Reports today and you can:

- Submit as many cases as you like

- Enjoy fast sympathetic peer review and rapid publication of accepted articles

Access all the published articles

Re-use any of the published material for personal use and teaching without further permission

For information on Institutional Fellowships contact consortiasales@bmjgroup.com

Visit casereports.bmi.com for more articles like this and to become a Fellow 